\title{
The Naueti relationship terminology A new instance of asymmetric prescription from East Timor
}

Relationship terminologies of an asymmetric prescriptive character are widespread throughout mainland and insular Southeast Asia. Their western limit is marked by the Kachin of northern Burma (Leach 1961:28-53) while their eastern limit is marked by the Mambai people of central East Timor (Figures 1 and 2). Between these limits are such other instances as occur, for example, among the Lamet of Cambodia (Needham 1960), the various Batak groups of Sumatra (Rodgers 1984), and the Rindi of eastern Sumba (Forth 1981). The principal intention of the present paper is to establish the existence of a new asymmetric prescriptive terminology in East Timor, and by doing so provide empirical justification for adjusting the easternmost limits of nomenclatures of this kind. A subsidiary intent is to offer a contribution to current speculations regarding the transformation of relationship terminologies in eastern Indonesia (Guermonprez 1998; Smedal 2002).

\section{Introduction}

In terminologies of asymmetric prescriptive alliance one may expect the matrilateral cross-cousins and patrilateral cross-cousins to be terminologically distinguished (for example, MBD $\neq \mathrm{FZD}$ ), like certain other categories of relative, and typically one finds that such terminologies are supported by a rule that prescribes marriage for male ego with a category of woman that includes the mother's brother's daughter while proscribing marriage with a category of wo-

DAVID HICKS is Professor of Anthropology at Stony Brook University. He holds Doctor of Philosophy degrees from the University of Oxford and the University of London. His scholarly specializations are in kinship, ritual, oral literature, politics, and Southeast Asia. Dr Hicks has carried out field research in East Timor and in Flores. His books include Tetum ghosts and kin: Fertility and gender in East Timor, Long Grove Illinois: Waveland Press, 2004, and A maternal religion; The role of women in Tetum myth and ritual, DeKalb: Northern Illinois University, 1984. His papers have appeared in the American Anthropologist, The Journal of the Royal Anthropological Society, Oceania, Anthropos, and Sociologus, as well as in a number of anthologies. Professor Hicks can be contacted at the Department of Anthropology, Stony Brook University, Stony Brook NY 11794-4364, USA. Email: dhicks@notes.cc.sunysb.edu. 


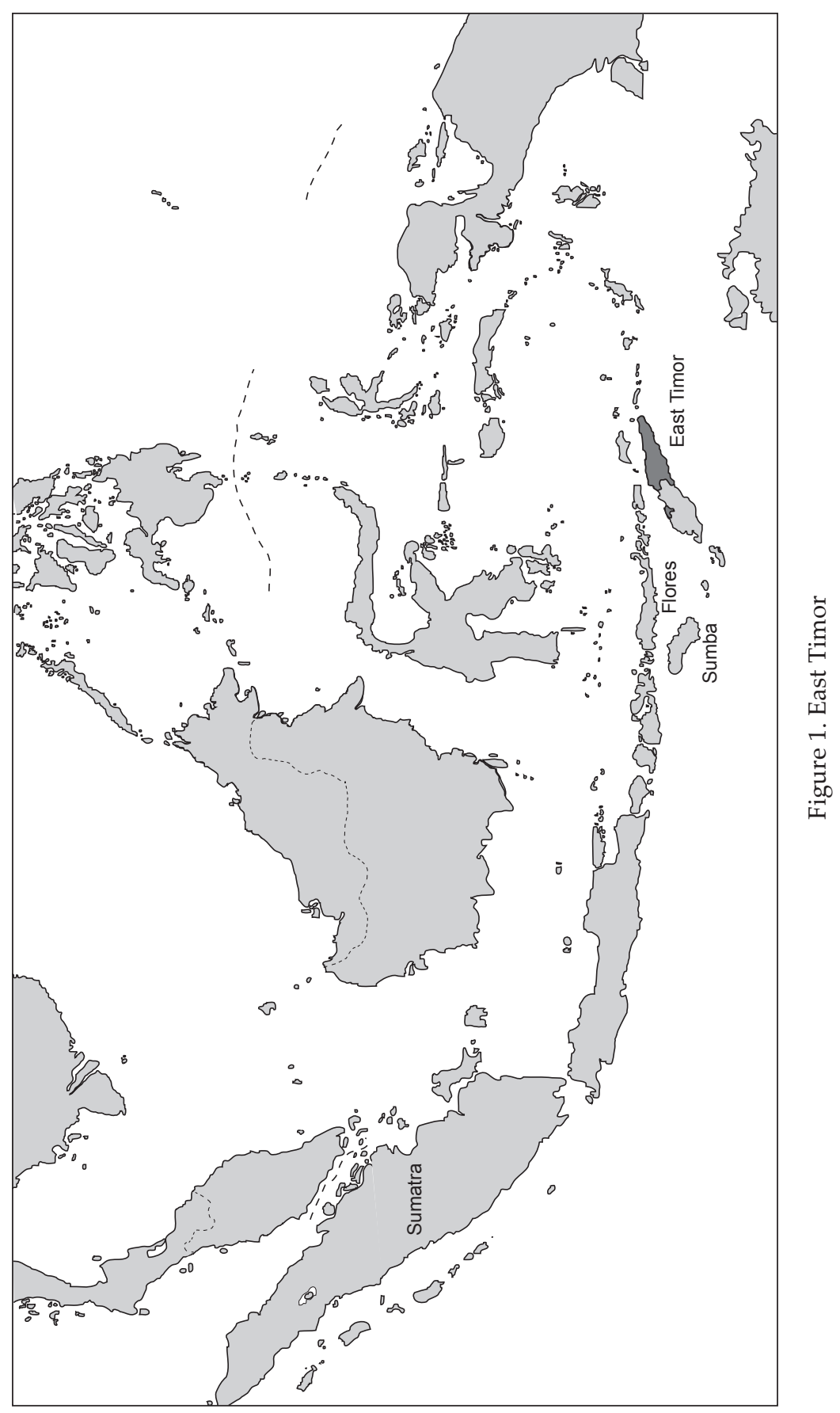




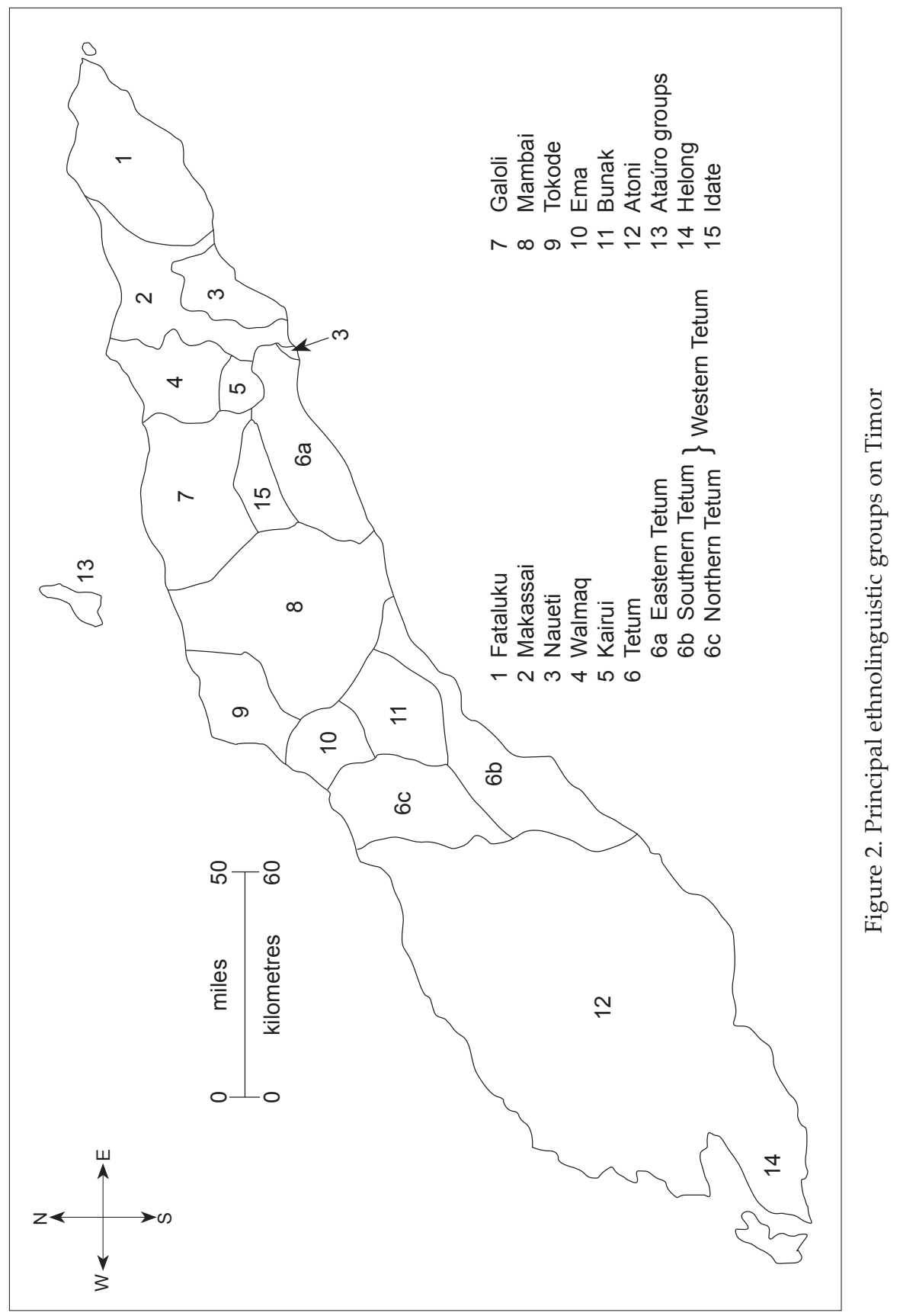


man that includes the father's sister's daughter. ${ }^{1}$ In many instances the structure of the terminology and concomitant marriage rule converges with institutional arrangements 'on the ground', so that male ego's descent group contracts affinal alliances with specified descent groups ('wife-givers') that provide his own group with wives, and other - clearly distinguished - specified descent groups ('wife-takers') that receive his own group's female kin (for example, sisters, father's sisters, and daughters) as wives. The respective statuses of wife-giver and wife-taker are exclusive. Wife-giving descent groups may not receive women from ego's descent group nor do ego's wife-taking partners provide his own descent group with wives. In contrast, in a symmetric terminology of prescription (or 'two-section' system) both matrilateral cross-cousins and patrilateral cross-cousins are conjoined into a single category (for example, MBD = FZD) and the rule of marriage may permit marriage with either. However, in some instances, although a symmetric terminology is employed, there may still be a prohibition against marriage between male ego and his female patrilateral crosscousin, with the result that the same triadic structure of affinal alliances, that is, wife-giver/ego's descent group/wife-taker, that one finds with a terminology of asymmetric prescriptive alliance, is in force. The (symmetric) terminology and the (asymmetric) alliance system are thus disjunctive. This heterology recurs in several other combinations, for example, asymmetric alliance accompanied by a non-prescriptive terminology (Hicks 1987) or a terminology of asymmetric prescriptive alliance unaccompanied by asymmetric alliance (Barnes 1974). Instances of these and other combinations are well-displayed in eastern Indonesia, which, since F.A.E. van Wouden published his Sociale structuurtypen in de Groote Oost in 1935, has gained recognition as an area in which the changes are rung on a number of variations and combinations of terminology and alliance.

In particular, East Timor (Figures 1 and 2), with approximately fifteen ethnolinguistic groups within a relatively small region, offers an unusually promising laboratory for the comparative study of these variations and combinations, for while asymmetric alliance is so prominent and pervasive a feature of the social organizations of almost all the populations of East Timor as to be considered virtually their defining feature, we find it combined with all manner of nomenclatures. Although notable instances also occur on the islands of Sumba and Flores, as well as in the western half of Timor, in East Timor the presence of the barlaque (as the institution is widely called) is so ubiquitous that to date only in one small area of the country is it known not to be practised. ${ }^{2}$ Even after twenty-four years of occupation by the military forces of the

1 From the perspective of female ego the prescriptions and proscriptions are the reverse, that is, marriage with a category of male that includes father's sister's son being enjoined and marriage with a category of male that includes mother's brother's son being forbidden.

2 In the Viqueque subdistrict in Viqueque district among certain Tetum-speaking communities (Hicks 2004). 
Republic of Indonesia, a period attended by intense 'modernization' of social norms, this perduring institution continues to direct the social lives, harness the cultural energies, and focus the psychological resources of its people. Indeed, so powerful an influence does the barlaque continue to exercise even today, that the massive expenditure of economic resources it entails renders 'matrilateral cross-cousin' marriage a lightening rod for strictures from some modern-minded Timorese aware of the profound discrepancy between the economic status of a nation enmeshed in poverty and the vibrancy of an institution in which the giving of dozens of buffaloes, ${ }^{3}$ the prime component of bridewealth, is commonplace at marriage. And buffaloes are but one component of the total set of marital prestations. ${ }^{4}$

For several years now I have been analysing Timorese relationship terminologies with a view to eliciting their structural characteristics and discerning their common features. Results thus far indicate that although the institution of asymmetric alliance is itself virtually ubiquitous among the island's populations, the same constancy is not apparent in their terminologies. Thus, whereas the people speaking Bunak, ${ }^{5}$ Ema, ${ }^{6}$ Mambai, ${ }^{7}$ Kairui, ${ }^{8}$ Makassai, ${ }^{9}$ and Fataluku, as well as most Tetum, practise asymmetric alliance as an institution, one ethnic group (the Bunak (Hicks 1987)) accompanies it with a non-prescriptive terminology; three (Atoni (Cunningham 1967), Northern Tetum (Hicks 1981, 1989) and Fataluku ${ }^{10}$ ) with symmetric prescriptive terminologies; two (Ema (Hicks 1986) and Mambai (Hicks 1978)) with asymmetric prescriptive terminologies; and two (Kairui (Hicks 1973, 1990 ${ }^{11}$ ) and Makassai (Hicks 1983)) with terminologies transitional between symmetry and asymmetry. Following Rodney Needham's suggestion (1967) that the comparative study of terminologies might derive benefit from a diachronic approach, I proposed in an earlier paper (Hicks 1990) a tentative schema for the evolution of terminologies in the Timor region. The directing force for what might be referred to as the 'directionality' sequentially followed by a hypothetical terminology was that of increasing complexity. That is, there was an evolution from the mode of terminology Needham considered to represent the simplest form, in this instance symmetric

3 Of all the ethnolinguistic populations, the Fataluku (see Figure 2) have the reputation for giving the highest bridewealth among the Timorese, one hundred and fifty beasts being the number often cited.

4 In addition horses, jewellery, and money would also be included.

5 Alternative renderings: 'Buna', 'Bunaq'.

6 Alternative rendering: 'Kemak'.

7 Alternative rendering: 'Mambae'.

8 Alternative rendering: 'Cairui'.

9 Alternative rendering: 'Makassae'.

10 Dr Maria Olímpia Lameiras-Campagnolo and Henri Campagnolo (personal communication 1989).

11 In the former analysis (Hicks 1973) I had originally characterized the Kairui relationship terminology incorrectly as symmetric. 
alliance, progressing through several intermediate stages to the most complex, non-lineal or cognatic. Although there are certain nuanced differences, the polar representatives of his construct are congruent with Claude Lévi-Strauss's 'elementary structures' and 'complex structures' (1949), and my model of eastern Timorese terminological evolution adopted Needham's argument regarding the direction of the terminological progression.

Logically, of course, the opposite directionality would be possible, and such an alternative model has been proposed by Jean-François Guermonprez (1998) and found consistent with the ethnography of a central Flores population, the Ngadha (Smedal 2002). Guermonprez's analysis is based upon the analysis of the categories of the three medial genealogical levels (first ascending, ego's level, and first descending) employed in the relationship terminologies of twenty-one societies in the South Moluccas. In his model a non-lineal terminology evolves through intermediary stages in the direction of asymmetry, and Olaf H. Smedal (2002) finds in the social facts of Ngadha ethnography data that lend empirical substance to Guermonprez's theory. So pertinent are his data that they enable him to provide an alternative force for the evolution of the terminologies of eastern Indonesia. He suggests that the

geographically delimitable, disparate bridewealth arrangements that the Ngadha evince may, over time, result in a realization that one's interests are best served if those arrangements are complemented by either a full-fledged asymmetric, lineal terminology [...] or a dismantling of the bridewealth institution altogether [...] (Smedal 2002:519).

Both directional models are admittedly speculative since the historical information necessary to verify their validity is lacking, but speculation of this sort nevertheless has a heuristic value in that it enables one to compare the characteristics of different relationship systems according to a distinct perspective which would otherwise be unavailable. And so, by way of ancillary intent, the present paper attempts to compare the structure of the Naueti terminology with those of certain other terminologies in the region by using both diachronic models, that of Needham's and that of Guermonprez's.

\section{Ethnographic background}

The nation of East Timor is divided into thirteen administrative districts, each of which comprises a number of subdistricts. Subdistricts in East Timor are made up of indigenous socio-political conglomerations known as suku (or aldeia), which themselves are composed of hamlets. The focus of life for the $80 \%$ or so of the population who live outside the capital, is the $s u k u$, at which level 
of regional administration indigenous polity and governmental bureaucracy converge. The Naueti-speaking ${ }^{12}$ people (Figure 2), who by one estimate today number around 6,000 (Saunders 2002-03:79), are one of the smaller ethnolinguistic groups. They are also among the least ethnographically known in eastern Indonesia, for apart from linguistic data ${ }^{13}$ the only information extant about them consists of a summary in Portuguese of an origin myth (Almeida 1990:592). The Naueti are located in two quite separate areas in the far eastern part of Timor. ${ }^{14}$ The largest by far comprises the subdistrict of Baguia, in the district of Baucau, and the two subdistricts, Uato Carabau and Uato Lari, in the district of Viqueque, where they occupy a landscape whose topography includes mountains rising more than 2,000 metres to form the island's backbone, foothills that descend southwards to the Timor Sea, and coastal lowlands abutting the sea itself. Much of their habitat consists of savanna interspersed with secondary woodland. Most Naueti suku are located in Uato Carabau, all six of which are Naueti-speaking. In Uato Lari, Naueti-speakers share the subdistrict with speakers of Makassai, and occupy three suku, while Baguia subdistrict contains three Naueti suku. The second Naueti area, which is located on the savanna-covered coastal lowlands, consists of a few villages in Viqueque subdistrict in the vicinity of Beasu village.

Linguists classify the vernacular languages of Timor into two principal categories, the Austronesian family of languages and those usually referred to as 'non-Austronesian'. The linguist Geoffrey Hull and his colleagues argue that these Austronesian languages appear to have derived from an ancestor language (or group of related dialects) spoken in the Muna-Buna-Tukang Besi zone of southeastern Sulawesi and thence, via several migrations and various 'stopovers' en route, transmitted to Timor. These migrants included some from the four islands of Tukang Besi in southeastern Sulawesi and, coming via Wetar (Hull 1998:149-53), became the Austronesian-speaking ancestors of what he refers to as the 'Kawamina' ${ }^{15}$ group of dialects (Naueti, Waimaha, ${ }^{16}$ Kairui, and Midiki), who he postulates may have arrived on Timor around the eleventh century AD. There they encountered speakers of non-Austronesian languages who themselves had descended from earlier waves of immigrants arriving sometime before the birth of Christ, and over the centuries that followed, the ancestral language of today's Kawamina

12 Alternative renderings: 'Nauhete', 'Nauéti', Nauoti. 'The name Naueti (also Nauoti) literally means 'now' (nau eti, literally 'this time'): the word was arbitrarily taken as a representative Naueti word by their Makassai neighbours and applied as the name of the language (Saunders 2002-03:79).

13 See Capell 1943/1944; Hull 1998; Saunders 2002-03.

14 See Figure 2, which shows most of the ethnolinguistic groups.

15 This is a hypothetical mother-language, the name of which Hull has formed from the first syllable of each dialect.

16 Alternative renderings: 'Waima'a', 'Uai Ma'a'. 
dialects was influenced by these non-Austronesian languages. Of the four dialects, Waimaha, Kairui, and Midiki display the most intimate linguistic connections, Naueti being sufficiently distant to warrant speculation that it might actually be more appropriately classed as a language in its own right rather than as a mere dialect.

Naueti subsistence is based on the cultivation of rice (both irrigated and dry), maize, greens, legumes, and root crops, as well as animal husbandry that includes the raising of goats, pigs, chickens, buffaloes, and horses. Prior to the Indonesian army's disruption of their settlement pattern, a group of agnatically related males and their unmarried sisters formed the residential core of houses, a localized group known as the baha, a term also denoting 'hamlet', the basic unit of the social organization. These baha are components of a larger entity called the wari-kaka, which are descent groups of variable segmentary character that may be appropriately glossed as 'patrilineage', or 'patrilineal subclan', or 'patrilineal house' (in the more inclusive sense of descent group segment). The term itself is a compound designation in which wari means 'younger', 'younger agnate of ego's genealogical level' and kaka means 'elder', 'elder agnate of ego's genealogical level'. It denotes both sexes. ${ }^{17}$ Agnates may also be called by a term of even wider application, bada, ${ }^{18}$ which includes affines, and used in a more precise sense may denote 'husband'. Hamlets were formerly scattered throughout Naueti territory, but under the Indonesian occupation, which began in December 1975, were abandoned when the military forces congregated hamlet residents into encampments adjacent to roads where they could more conveniently be supervised. With the attainment of East Timor's independence in May 2002, however, hamlet dwellers, more especially older ones, began returning to their abandoned ancestral lands to reclaim the patrimony of their descent groups.

Today, as before the occupation, Naueti adat ${ }^{19}$ enjoins that upon the death of their owner land, crops, livestock, and other such items of wealth as a man may have accumulated during the course of his lifetime accrue in the main to his male descendants. Political office, including that of traditional chief of the suku, a leader known as the liurai, also devolves upon men agnatically related to distant ancestors, and the inheritance of such rights (together with their concomitant duties) as family name, descent group membership, and totemic observances pass down the male line. This patrilineal mode of reckoning descent is reinforced by a patrilocal post-marital residence for a husband, a right that is secured by the giving of bridewealth.

17 The term corresponds to the widespread and more commonly known Tetum category alimaun.

18 It is the Naueti equivalent of the Tetum term maluk.

19 This Malay term was not used in pre-Indonesian times to any widespread extent. Nowadays it is common currency. 
Before the relocation into encampments, the most conspicuous index of Naueti patri-identity was the ritual house, which - tellingly - is also known as baha. $^{20}$ These baha are reliquaries housing a diverse array of sacra comprised of physical memorabilia suffused with mytho-legendary connotations. They include war swords, fragments of sacred pots, and other material manifestations of the link between living kin and their ghostly agnatic forebears. In some ritual houses one also finds artefacts justifying claims to land rights and entitlement to political offices. Included, too, are often fragments of old Portuguese flags, and documents dating to Portuguese colonial days authenticating entitlements to various military distinctions conferred upon the ancestors of the baha by the Europeans.

The ritual house also serves as the principal physical locus for ritual activity that connects those responsible for its upkeep to their ancestors, and as such is a place of sacrifice to these ghostly entities. Under the occupation, the ritual houses were either burned down by the Indonesian military or left to fall into a state of decay after their owners had been forced into the encampments. Now, however, with the return of many baha residents to ancestral lands, the reconstruction of these buildings has emerged as a dynamic force in contemporary Naueti society. Under the occupation sacred heirlooms, such as would in former times be enshrined in the ritual houses, were buried in the ground for safe-keeping. Now that the families are returning to their ancestral lands, these heirlooms are being dug up and restored to their rightful place in rebuilt ritual houses. ${ }^{21}$

Today, while most Naueti profess to be Catholic, traditional convictions regarding the influence ancestral ghosts have on daily life continue to exercise control over individuals. Naueti adat confounds the Indonesian agama in such pagan rituals as sacrificial offerings to ancestors, rain-making, and the rite of 'calling to the crocodiles'. In this local pursuit of adat the ritual house provides the material basis for the agnatically-linked baha group and serves the individual as his or her emblem of social identity, a symbol reinforced verbally in the conflation of the three indigenous notions of descent group, hamlet, and ritual house in the term baha.

The association between descent group and ritual includes the notion that the ancestral ghosts are the agency responsible for conferring fertility on human beings, and by withholding this essential resource have the power to inflict sterility and death - the ultimate expression of infertility - upon

20 Elsewhere in East Timor these edifices are called uma lulik. In other parts of eastern Indonesia they are sometimes referred to as 'cult houses'.

21 Even in the construction of ordinary houses, the Naueti are replicating the style of house they built before the time of the Indonesian occupation, following, in as much detail as possible, the particulars of the former style and eschewing the corrugated roofs mandated by the Indonesian authorities. 
individuals. Accordingly, when an individual is sick or a marital union is proving barren, the parties concerned may consult a malu rae, a ritual practitioner whose functions include divination, to determine the source of the affliction. ${ }^{22}$ Should ancestral chagrin be diagnosed, the malu rae will suggest a remedy. This is likely to take the form of a ritual of expiation to the ghosts that, besides involving a sacrifice, might include restoring a ritual house to something resembling its former condition or even building a new one to replace one that was destroyed in Indonesian times. For several years after his marriage, one of my informants and his wife had sought to have a baby. After the first pregnancy resulted in the early death of the infant and the second terminated in a miscarriage, the couple unavailingly looked to western medicine to provide a remedy. They next resorted to their adat and consulted a malu rae, who diagnosed as the cause of their misfortune the failure of the husband and his wari-kaka to maintain the lineage ancestors' graves in a respectful condition. The husband forthwith undertook to atone for his neglect of ghostly needs, and following a supplementary suggestion made by the malu rae undertook, with the aid of wari-kaka, the reconstruction of their ritual house, which had fallen into disrepair. The building, a conspicuous monument to Naueti concepts of agnation, in spiritual form as well as in fleshly substance, stands today on a slope commanding a dramatic view of Mate Bein (Ancestral Ghosts), Timor's second tallest mountain. ${ }^{23}$ Some time after its completion the wife became pregnant, and their child was born in 2004. Unlike its predecessors, the infant survived. Since that time, my informant told me, no one in his family has fallen ill.

\section{Relationship terminology}

The Naueti terms of reference and address for a male and a female are displayed separately in Tables 1-4, which reveal them to resemble one another more closely than is the case among certain other ethnic groups in eastern Indonesia, for example, the Kédang (Barnes 1974:265-81) or Rindi (Forth 1981:302-27).

22 In the Tetum-speaking area of Timor this practitioner is known as the matan do'ok.

23 A coloured portrait of the ritual house provided the desktop of his computer with a colourful backdrop when I glimpsed it in July 2005. 
Table 1. Nauhete relationship terms (reference, male ego)

\begin{tabular}{|c|c|c|}
\hline 01. sodé & & 5th ascending and descending genealogical levels \\
\hline 02. nanu & & 4th ascending and descending genealogical levels \\
\hline 03. luli & & 3rd ascending and descending genealogical levels \\
\hline \multirow[t]{3}{*}{$04 . b u$} & & 2nd ascending and descending genealogical levels \\
\hline & bu asukai & all male $b u$ \\
\hline & bu ona-ata & all female $b u$ \\
\hline \multirow[t]{3}{*}{ 05. amau } & & F, FB, MZH, FFBS, FMZS, MFZS, MZHB, ZHMB \\
\hline & kaka aname & FeB \\
\hline & ware aname & FyB \\
\hline 06. inau & & M, MZ, FW, FBW, MFBD, FBWZ, FMBD, MMZD, FMBD, WFZ, BWFZ \\
\hline \multirow[t]{4}{*}{$07 . o b u$} & & MB, WF, BWF, WFB, FBWB, MFBS, MMZS, MBFS, MMZS, FMBS, FBWB, \\
\hline & & MBWB, WM, MBW, BWM, FZHZ, WMZ, MFBSW, MMZSW, MBWZ, FMBSW \\
\hline & obu asukai & all male obu \\
\hline & obu ona-ata & all female $o b u$ \\
\hline \multirow[t]{3}{*}{ 08. $\operatorname{simu}$} & & WF,WM \\
\hline & simu asukai & WF \\
\hline & simu ona-ata & WM \\
\hline 09. inau-tua & & FZ, FFBD, FMZD, ZHM, MZHZ, FFBD, FMZD, MZHZ, FZHW \\
\hline 10. amau'dae & & FZH, ZHF, FFBDH, FMZDH, MZHZH, ZHF, FZHZH \\
\hline \multirow[t]{4}{*}{ 11. kaka } & & eB, FBSe, FFBSSe, MZSe, WZHe, FZSWBe, ZHBWBe, FWSe, eZ, FBDe, MZDe \\
\hline & & FBSDe, FFBSDe, FWDe \\
\hline & kaka asukai & all male kaka \\
\hline & kaka ona-ata & all female kaka \\
\hline \multirow[t]{4}{*}{ 12. wari } & & yB, FBSy, FFBSSy, FWSy, FZSWBy, MZSy, WZHy, ZHBWBy, yZ, \\
\hline & & FBDy, FFBSDy, FWDy, MZDy \\
\hline & wari asukai & all male wari \\
\hline & wari ona-ata & all female wari \\
\hline 13. mae & & Z, FBD, MZD, FFBSD, MMZDD, FWD, FZSW, ZHBW, DHM, FFBSD \\
\hline 14. kria & & MBS, MFBSS, MMZSS, WB, BWB, SWF \\
\hline 15. bunara & & MBD, MFBSD, MMZSD, MMBDD, W, BW, FBSW, MZSW, WZ \\
\hline 16. kriana & & FZS, FMZDS, ZH, ZHB \\
\hline 17. buana & & FZD, FMZDD, ZHZ, FZHD \\
\hline 18. ona-ata & & W \\
\hline 19. ana & & S, BS, FBSS, MZSS, WZS, D, BD, FBSD, MZSD, WZD, ZSW, MBDSW, FZSSW \\
\hline \multirow[t]{4}{*}{ 20. andau } & & ZS, FBDS, MZDS, ZDH, ZHBS, DH, DHB, ZD, BDH, FBDD, \\
\hline & & MZDD, FZSD, ZHBD, FZDSW, ZHD, DHZ \\
\hline & andau asukai & all male andau \\
\hline & andau ona-ata & all female andau \\
\hline
\end{tabular}


Table 2. Nauhete relationship terms (reference, female ego)

\begin{tabular}{|c|c|c|}
\hline 01. sodé & & 5th ascending and descending genealogical levels \\
\hline 02. nanu & & 4th ascending and descending genealogical levels \\
\hline 03. luli & & 3rd ascending and descending genealogical levels \\
\hline \multirow[t]{3}{*}{ 04. $b u$} & & 2nd ascending and descending genealogical levels \\
\hline & bu asukai & all male $b u$ \\
\hline & bu ona-ata & all female $b u$ \\
\hline \multirow[t]{3}{*}{ 05. amau } & & F, FB, MZH, FFBS, FMZS, MFZS, MZHB, ZHMB \\
\hline & kaka aname & FeB \\
\hline & ware aname & FyB \\
\hline 06. inau & & M, MZ, FW, FBW, MFBD, FBWZ, FMBD, MMZD, FMBD, BWFZ \\
\hline \multirow[t]{4}{*}{ 07. obu } & & MB, BWF, FBWB, MFBS, MMZS, MBFS, MMZS, FMBS, FBWB, \\
\hline & & MBWB, MBW, BWM, FZHZ, MFBSW, MMZSW, MBWZ, FMBSW \\
\hline & obu asukai & all male obu \\
\hline & obu ona-ata & all female $o b u$ \\
\hline \multirow[t]{3}{*}{ 08. $\operatorname{simu}$} & & HF, HM \\
\hline & simu asukai & HF \\
\hline & simu ona-ata & HM \\
\hline 09. inau-tua & & FZ, HM, HMZ, FFBD, FMZD, ZHM, MZHZ, FFBD, FMZD, MZHZ, FZHW \\
\hline 10. amau'dae & & FZH, ZHF, FFBDH, FMZDH, MZHZH, ZHF, FZHZH \\
\hline \multirow[t]{4}{*}{ 11. kaka } & & eB, FBSe, FFBSSe, MZSe, FZSWBe, ZHBWBe, FWSe, eZ, FBDe, MZDe, \\
\hline & & FBSDe, FFBSDe, FWDe \\
\hline & kaka asukai & all male kaka \\
\hline & kaka ona-ata & all female kaka \\
\hline \multirow[t]{4}{*}{ 12. wari } & & yB, FBSy, FFBSSy, FWSy, FZSWBy, MZSy, ZHBWBy, yZ, FBDy, FFBSDy, \\
\hline & & FWDy, MZDy \\
\hline & wari asukai & all male wari \\
\hline & wari ona-ata & all female wari \\
\hline 13. mae & & B, FBS, MZS, FFBSS, MMZDS, FWS, SWZB, FFBSS, SWF \\
\hline 14. kria & & MBS, MFBSS, MMZSS, BWB \\
\hline 15. bunara & & MBD, MFBSD, MMZSD, MMBDD, W, BW, FBSW, MZSW, WZ \\
\hline 16. kriana & & FZS, FMZDS, ZH, ZHB \\
\hline 17. buana & & FZD, FMZDD, ZHZ, FZHD \\
\hline 18. laki & & $\mathrm{H}$ \\
\hline 19. ana & & S, BS, FBSS, MZSS, D, BD, FBSD, MZSD, ZSW, MBDSW, FZSSW \\
\hline
\end{tabular}


Table 3. Nauhete relationship terms (address, male ego)

\begin{tabular}{|c|c|}
\hline 01. sodé & 5th ascending and descending genealogical levels \\
\hline 02. nanu & 4th ascending and descending genealogical levels \\
\hline 03. luli & 3rd ascending and descending genealogical levels \\
\hline $04 . b u$ & 2nd ascending and descending genealogical levels \\
\hline 05. amau & F, FB, MZH, FFBS, FMZS, MFZS, MZHB, ZHMB \\
\hline 06. inau & M, MZ, FW, FBW, MFBD, FBWZ, FMBD, MMZD, FMBD, WFZ, BWFZ \\
\hline \multirow[t]{2}{*}{ 07. obu } & MB, WF, BWF, WFB, FBWB, MFBS, MMZS, MBFS, MMZS, FMBS, FBWB, MBWB, WM, \\
\hline & MBW, BWM, FZHZ, WMZ, MFBSW, MMZSW, MBWZ, FMBSW \\
\hline 08. $\operatorname{sim} u$ & WF, WM \\
\hline 09. inau-tua & FZ, FFBD, FMZD, ZHM, MZHZ, FFBD, FMZD, MZHZ, FZHW \\
\hline 10. amau'dae & FZH, ZHF, FFBDH, FMZDH, MZHZH, ZHF, FZHZH \\
\hline \multirow[t]{2}{*}{ 11. kaka } & eB, FBSe, FFBSSe, MZSe, WZHe, FZSWBe, ZHBWBe, FWSe, eZ, FBDe, MZDe, FBSDe, \\
\hline & FFBSDe, FWDe \\
\hline \multirow[t]{2}{*}{ 12. wari } & yB, FBSy, FFBSSy, FWSy, FZSWBy, MZSy, WZHy, ZHBWBy, yZ, \\
\hline & FBDy, FFBSDy, FWDy, MZDy \\
\hline 13. mae & Z, FBD, MZD, FFBSD, MMZDD, FWD, FZSW, ZHBW, DHM, FFBSD \\
\hline 14. kria & MBS, MFBSS, MMZSS, WB, BWB, SWF \\
\hline 15. bunara & MBD, MFBSD, MMZSD, MMBDD, W, BW, FBSW, MZSW, WZ \\
\hline 16. kriana & FZS, FMZDS, ZH, ZHB \\
\hline 17. buana & FZD, FMZDD, ZHZ, FZHD \\
\hline 18. ona-ata & W \\
\hline 19. ana & S, BS, FBSS, MZSS, WZS, D, BD, FBSD, MZSD, WZD, ZSW, MBDSW, FZSSW \\
\hline \multirow[t]{2}{*}{ 20. andau } & ZS, FBDS, MZDS, ZDH, ZHBS, DH, DHB, ZD, BDH, FBDD, \\
\hline & MZDD, FZSD, ZHBD, FZDSW, ZHD, DHZ \\
\hline
\end{tabular}


Table 4. Nauhete Relationship Terms (Address, Female Ego)

\begin{tabular}{|l|l|}
\hline 01. sodé & 5th ascending and descending genealogical levels \\
\hline 02. nanu & 4th ascending and descending genealogical levels \\
\hline 03. luli & 3rd ascending and descending genealogical levels \\
\hline 04. bu & 2nd ascending and descending genealogical levels \\
\hline 05. amau & F, FB, MZH, FFBS, FMZS, MFZS, MZHB, ZHMB \\
\hline 06. inau & M, MZ, FW, FBW, MFBD, FBWZ, FMBD, MMZD, FMBD, BWFZ \\
\hline 07. obu & MB, BWF, FBWB, MFBS, MMZS, MBFS, MMZS, FMBS, FBWB, MBWB, MBW, BWM, FZHZ, \\
\hline & MFBSW, MMZSW, MBWZ, FMBSW \\
\hline 08. simu & HF,HM \\
\hline 09. inau-tua & FZ, HM, HMZ, FFBD, FMZD, ZHM, MZHZ, FFBD, FMZD, MZHZ, FZHW \\
\hline 10. amau'dae & FZH, ZHF, FFBDH, FMZDH, MZHZH, ZHF, FZHZH \\
\hline 11. kaka & eB, FBSe, FFBSSe, MZSe, FZSWBe, ZHBWBe, FWSe, eZ, FBDe, MZDe, FBSDe, FFBSDe, FWDe \\
\hline 12. wari & yB, FBSy, FFBSSy, FWSy, FZSWBy, MZSy, ZHBWBy, yZ, FBDy, FFBSDy, FWDy, MZDy \\
\hline 13. mae & B, FBS, MZS, FFBSS, MMZDS, FWS, SWZB, FFBSS, SWF \\
\hline 14. kria & MBS, MFBSS, MMZSS, BWB \\
\hline 15. bunara & MBD, MFBSD, MMZSD, MMBDD, W, BW, FBSW, MZSW, WZ \\
\hline 16. kriana & FZS, FMZDS, ZH, ZHB \\
\hline 17. buana & FZD, FMZDD, ZHZ, FZHD \\
\hline 18. laki & H \\
\hline 19. ana & S, BS, FBSS, MZSS, D, BD, FBSD, MZSD, ZSW, MBDSW, FZSSW \\
\hline
\end{tabular}

Before proceeding with my analysis, some preliminary observations regarding certain features of the nomenclature need to be remarked.

a. Some foreign words from contemporary languages have made their way into the Naueti relationship terminology and are heard in daily speech as alternatives to the vernacular. These include the Portuguese tio denoting 'uncle' or 'mother's brother' and sobrinha denoting 'niece'; the Malay laki denoting 'husband'; the Makassai ina tua as an alternative term denoting 'father's sister'; and the Tetum word ama as in the compound ama-dae denoting 'father's sister's husband'. Apart from laki, which is likely to be of long-standing use, these alternatives tend to be redundant to the vernacular idiom registered in the tables.

b. The term ana, which denotes 'child' as well as most young persons of ego's child's genealogical level, helps form the compounds buana and kriana.

c. In keeping with the convention common to Timor and widespread throughout the eastern archipelago, a number of Naueti radical terms are inflected to signify gender by the use of suffixes. In the Naueti nomenclature asukai ('male', 'man',' husband') and ona-ata ('female', 'woman', 'wife') respectively modify bu, obu, simu, wari, kaka, and andau. 
d. Another feature of the terminology, though one common among Timorese ethnolinguistic groups, is that after marriage affinal terms become available as optional designations for certain relatives previously referred to and addressed by collateral terms. Before her marriage a woman refers to and addresses her father's sister's son as kriana. If she marries him she will call him laki, in addition to having the generic bada available. Similarly, before his marriage a man refers to and addresses his mother's brother's daughter as bunara. Should he marry her, the woman becomes his ona-ata ('wife'), with the term $i$ as an alternative. Before marriage a man refers to and addresses his mother's brother as obu; after marriage he may call the senior man simu, although since the former term conveys more respect $o b u$ is normally preferred. Correspondingly, whereas before marriage a woman will refer to and address her father's sister's husband as amau'dae, after marriage he, too, may be addressed and referred to as simu.

e. As previously noted, there are relatively insignificant differences between Naueti terms of reference and terms of address, the Naueti tendency being to follow the least complicated usage. The most salient difference between reference and address is that asukai and ona-mata may be affixed to the former, but not normally to the latter. The wife's father, for instance, might be referred to as simu-asukai, but would be addressed as simu.

f. A conspicuous feature of Naueti terminology is the symmetry between the four senior ascending genealogical levels and the four junior descending genealogical levels (see Tables 5-8), in which the oldest members and youngest members of the terminological system are brought together. Although this symmetric feature also occurs in Kairui (Hicks 1973), Makassai (Hicks 1983), and in some Tetum dialects (Hicks 1981), its appearance in the fourth and fifth genealogical levels has not been reported for these nomenclatures.

g. One of the terms implicated in this reciprocal arrangement is luli, a denotation for persons of the third ascending and third descending genealogical levels, which offers singular interest because although the term luli $(k)$ occurs in all described Timorese languages, only among the Naueti is it incorporated into the relationship terminology. This is intriguing not only because among the referents of the term are the notions of 'forbidden', 'proscribed', and 'sacred', but because luli is one of the most pervasive répresentations collectives in Naueti ritual life, so prominent in fact that it may be said to exemplify Evans-Pritchard's celebrated asseveration (1951:80) that 'the most difficult task in anthropological fieldwork is to determine the meanings of a few key words, upon an understanding of which the success of the whole investigation depends [...]'. In conflating a social relationship and a set of metaphysical notions, Naueti social thought may be understood as attributing a common identity to both grandparents and grandchildren, thereby establishing an association, described elsewhere 
in Timor, between death and life as represented respectively by a past generation (grandparents) and a future generation (grandchildren) (Hicks 2004:132-3). In that the term luli assimilates within itself referents pertaining to the spheres of kinship and the sacred, it somewhat resembles the term baha which, as remarked, denotes the ritual house, descent group, and hamlet. Through their common membership of a descent group, ancestors, who represent the realm of the sacred (luli) and whose material abode is the ritual house, and their living kin who live in hamlets that embrace these ritual edifices, share in the same social and metaphysical identity.

After these preliminary remarks we may now turn to the analysis itself. The following equations and distinctions are diagnostic of lineal descent. They do not exhaust all the possible ones contained in the relationship terminology, but more than suffice to demonstrate that the terminology is lineal in character:

\begin{tabular}{|c|c|c|c|c|}
\hline $\mathrm{F}$ & FB & FB & $\neq$ & $\mathrm{MB}$ \\
\hline FB & MZH & FZ & $\neq$ & MZ \\
\hline $\mathrm{M}$ & MZ & FBS & $\neq$ & FZS \\
\hline B & FBS & FBS & $\neq$ & MBS \\
\hline FBS & MZS & FBD & $\neq$ & FZD \\
\hline Z & FBD & FBD & $\neq$ & MBD \\
\hline FBD & MZD & BS & $\neq$ & ZS \\
\hline S & BS & $\mathrm{BD}$ & $\neq$ & ZD \\
\hline BS & FBSS & & & \\
\hline FBSS & MZSS & & & \\
\hline D & BD & & & \\
\hline $\mathrm{BD}$ & FBSD & & & \\
\hline FBSD & MZSD & & & \\
\hline
\end{tabular}

The following equations and distinctions, which are also not exhaustive, are diagnostic of asymmetric prescriptive alliance:

$\begin{array}{ll}\mathrm{FB} & =\mathrm{MZH} \\ \mathrm{MZ} & =\mathrm{FBW} \\ \mathrm{MB} & =\mathrm{WF} \\ \mathrm{MBW} & =\mathrm{WM} \\ \mathrm{MBS} & =\mathrm{WB} \\ \mathrm{MBD} & =\mathrm{W} \\ \mathrm{MBD} & =\mathrm{WZ} \\ \mathrm{FZS} & =\mathrm{ZH} \\ \mathrm{FZD} & =\mathrm{ZHZ} \\ \mathrm{DH} & =\mathrm{ZS}\end{array}$

$\begin{array}{lll}\text { WF } & \neq & \text { FZH } \\ \text { FZ } & \neq & \text { WM } \\ \text { MBS } & \neq & \text { FZS } \\ \text { MBD } & \neq & \text { FZD } \\ \text { FZS } & \neq & \text { WB } \\ \text { WB } & \neq & \text { ZH }\end{array}$

Organized into their respective matrices, the radical categories of descent and alliance are shown in Table 5 for terms of reference used by male ego, in Table 6 for terms of reference used by female ego, in Table 7 for terms of address used by male ego, and in Table 8 for terms of address used by female ego. 
The structure displayed in each table is that of lineal descent and asymmetric prescription. The marriageable category for male ego is seen to be a female he terms bunara (Tables 5 and 7), and for female ego a male she terms kriana (Tables 6 and 8). It now remains to be seen how this terminology relates to Naueti rules governing marriage possibilities and the contraction of affinal alliances.

Table 5. Terms of reference, male ego

\begin{tabular}{|c|c|c|c|c|c|}
\hline \multicolumn{2}{|c|}{$\begin{array}{c}\text { oa sae (wife-takers) } \\
\leftarrow\end{array}$} & \multicolumn{2}{|c|}{$\begin{array}{c}\text { wari-kaka (ego's line) } \\
\leftarrow\end{array}$} & \multicolumn{2}{|c|}{$\begin{array}{c}\text { uma ana (wife-givers) } \\
\leftarrow\end{array}$} \\
\hline (female) & (male) & (female) & (male) & (female) & (male) \\
\hline \multicolumn{6}{|c|}{ soké } \\
\hline \multicolumn{6}{|c|}{ nanu } \\
\hline \multicolumn{6}{|c|}{ luli } \\
\hline \multicolumn{6}{|c|}{$b u$} \\
\hline $\begin{array}{l}\text { obu } \\
\text { simu }\end{array}$ & $\begin{array}{l}\text { amau'dae } \\
\text { simu }\end{array}$ & amau-tua & $\begin{array}{c}\text { kaka aname } \\
\text { amau } \\
\text { were aname }\end{array}$ & inau & $o b u$ \\
\hline buana & kriana & $\begin{array}{l}\text { kaka } \\
\text { mae } \\
\text { wari }\end{array}$ & $\begin{array}{c}\text { kaka } \\
\text { [ego] } \\
\text { wari }\end{array}$ & $\begin{array}{l}\text { bunara } \\
\text { ona-ata }\end{array}$ & kria \\
\hline andau & andau & ana & ana & ana & ana \\
\hline \multicolumn{6}{|c|}{$b u$} \\
\hline \multicolumn{6}{|c|}{ luli } \\
\hline \multicolumn{6}{|c|}{ nanu } \\
\hline \multicolumn{6}{|c|}{ soké } \\
\hline
\end{tabular}

Table 6. Terms of reference, female ego

\begin{tabular}{|c|c|c|c|c|c|}
\hline \multicolumn{2}{|c|}{$\begin{array}{c}\text { oa sae (wife-takers) } \\
\leftarrow\end{array}$} & \multicolumn{2}{|c|}{$\begin{array}{c}\text { wari-kaka (ego's line) } \\
\leftarrow\end{array}$} & \multicolumn{2}{|c|}{$\begin{array}{c}\text { uma ana wife-givers) } \\
\leftarrow\end{array}$} \\
\hline (female) & (male) & (female) & (male) & (female) & (male) \\
\hline \multicolumn{6}{|c|}{ soké } \\
\hline \multicolumn{6}{|c|}{ nanu } \\
\hline \multicolumn{6}{|c|}{ luli } \\
\hline \multicolumn{6}{|c|}{$b u$} \\
\hline$o b u$ & amau'dae & amau-tua & $\begin{array}{c}\text { kaka aname } \\
\text { amau } \\
\text { ware aname }\end{array}$ & inau & $o b u$ \\
\hline buana & $\begin{array}{c}\text { kriana } \\
\text { laki }\end{array}$ & $\begin{array}{c}\text { kaka } \\
\text { [ego] } \\
\text { wari }\end{array}$ & $\begin{array}{l}\text { kaka } \\
\text { mae } \\
\text { wari }\end{array}$ & bunara & kria \\
\hline ana & ana & ana & ana & ana & ana \\
\hline \multicolumn{6}{|c|}{$b u$} \\
\hline \multicolumn{6}{|c|}{ luli } \\
\hline \multicolumn{6}{|c|}{ nanu } \\
\hline \multicolumn{6}{|c|}{ soké } \\
\hline
\end{tabular}


Table 7. Terms of address, male ego

\begin{tabular}{|c|c|c|c|c|c|}
\hline \multicolumn{2}{|c|}{$\begin{array}{c}\text { oa sae (wife-takers) } \\
\leftarrow\end{array}$} & \multicolumn{2}{|c|}{$\begin{array}{c}\text { wari-kaka (ego's line) } \\
\leftarrow\end{array}$} & \multicolumn{2}{|c|}{$\begin{array}{c}\text { uma ana (wife-givers) } \\
\leftarrow\end{array}$} \\
\hline (female) & (male) & (female) & (male) & (female) & (male) \\
\hline \multicolumn{6}{|c|}{ soké } \\
\hline \multicolumn{6}{|c|}{ nanu } \\
\hline \multicolumn{6}{|c|}{ luli } \\
\hline \multicolumn{6}{|c|}{$b u$} \\
\hline $\begin{array}{l}\text { obu } \\
\text { simu }\end{array}$ & $\begin{array}{c}\text { amau'dae } \\
\text { simu }\end{array}$ & amau-tua & amau & inau & $o b u$ \\
\hline buana & kriana & $\begin{array}{l}\text { kaka } \\
\text { mae } \\
\text { wari }\end{array}$ & $\begin{array}{c}\text { kaka } \\
\text { [ego] } \\
\text { wari }\end{array}$ & $\begin{array}{l}\text { bunara } \\
\text { ona-ata }\end{array}$ & kria \\
\hline andau & andau & ana & ana & ana & ana \\
\hline \multicolumn{6}{|c|}{$b u$} \\
\hline \multicolumn{6}{|c|}{ luli } \\
\hline \multicolumn{6}{|c|}{ nanu } \\
\hline \multicolumn{6}{|c|}{ soké } \\
\hline
\end{tabular}

Table 8. Terms of address, female ego

\begin{tabular}{|c|c|c|c|c|c|}
\hline \multicolumn{2}{|c|}{$\begin{array}{c}\text { oa sae (wife-takers) } \\
\leftarrow\end{array}$} & \multicolumn{2}{|c|}{$\begin{array}{c}\text { wari-kaka (ego's line) } \\
\leftarrow\end{array}$} & \multicolumn{2}{|c|}{$\begin{array}{c}\text { uma ana (wife-givers) } \\
\leftarrow\end{array}$} \\
\hline (female) & (male) & (female) & (male) & (female) & (male) \\
\hline \multicolumn{6}{|c|}{ soké } \\
\hline \multicolumn{6}{|c|}{ nanu } \\
\hline \multicolumn{6}{|c|}{ luli } \\
\hline \multicolumn{6}{|c|}{$b u$} \\
\hline$o b u$ & amau'dae & amau-tua & amau & inau & $o b u$ \\
\hline buana & $\begin{array}{c}\text { kriana } \\
\text { laki }\end{array}$ & $\begin{array}{c}\text { kaka } \\
\text { [ego] } \\
\text { wari }\end{array}$ & $\begin{array}{l}\text { kaka } \\
\text { mae } \\
\text { wari }\end{array}$ & bunara & kria \\
\hline ana & ana & ana & ana & ana & ana \\
\hline \multicolumn{6}{|c|}{$b u$} \\
\hline \multicolumn{6}{|c|}{ luli } \\
\hline \multicolumn{6}{|c|}{ nanu } \\
\hline \multicolumn{6}{|c|}{ soké } \\
\hline
\end{tabular}




\section{Marriage and alliance rules}

The rules governing marriage are consistent with the structure of the terminology, most strikingly with the marriage categories bunara (for a male) and kriana (for a female), and accord with the rules governing an asymmetric regulation of marriage alliances. In social practice, marriage between a man and his genealogically-defined mother's brother's daughter (bunara) and a woman and her genealogically-defined father's sister's son (kriana) is strongly favoured, and though the Catholic Church disapproves of first-cousin marriage it remains a vibrant part of the social mores. ${ }^{24}$ Conversely, marriage between a man and his genealogically-defined father's sister's daughter (buana) and a woman and her genealogically-defined mother's brother's son $\left(\mathrm{kria}^{25}\right)$ is strongly disapproved by both church and people.

Nevertheless, as Forth (1981) has shown for the Rindi of Sumba and Molnar (2000) has shown for the Hoga Sara of central Flores, normative ideal and the pragmatics of social practice can diverge. Depending upon social, political, or economic advantages or, in some cases, necessities, individuals or descent groups may ignore the rule or adjust the nature of the traditional contract existing between the two alliance groups in such a manner that the direction of the alliance is reversed. Wife-givers become wife-takers while wife-takers become wife-givers. Terminologically speaking, individuals previously known by relationship terms identifying them as wife-givers will now be known by relationship terms appropriate to their new status as wifetakers, while individuals previously known by relationship terms identifying them as wife-takers will now be known by relationship terms appropriate to their new status as wife-givers. Regarded from the perspective of several generations, the alliance arrangements thus present the appearance of symmetry rather than asymmetry, a feature of asymmetric prescriptive systems Molnar (2000:132) has described for the Hoga Sara with a wealth of detail.

Such divergences aside, in Naueti alliances male ego's descent group (warikaka) takes wives from a number of specified wife-giving descent groups (uma ana) ${ }^{26}$ and gives its father's sisters, sisters, and daughters (among other women) as wives to a number of specified wife-taking descent groups (oa-sae). The direction cannot be reversed: uma ana cannot take women from their oasae. In other words, the direct exchange of women between descent groups is prohibited, a requirement that imparts asymmetry into the exchange. The segmentary structure of the alliance group (that is, the group that actually con-

24 It will be understood that these terms of relationship include second cousin, third cousin, and so forth, and that marriage with these would be entirely consistent with the institution of asymmetric prescriptive alliance. The same, mutatis mutandis, would apply for female ego.

25 Kria is a cognate of the term rian, which among Tetum-speakers is used as a term of reference and term of address for the siblings of a spouse of either sex.

$26 U m a=$ house; $a n a=$ child . 
tracts the alliances) varies according to circumstance. Sometimes lineages serve as the alliance groups; on other occasions it is segments of a lineage that carry out this function. As in systems of asymmetric alliance described elsewhere in Timor (Clamagirand 1987; Cunningham 1967; Hicks 1983), in the Naueti barlaque the alliance groups and the symbolic identity of the prestations received are consistent. The bridewealth is considered masculine and the wife-giving alliance group is classified as masculine; the counter-prestations are considered feminine and the wife-taking alliance group is classified as feminine. The bridewealth (otaweli) ${ }^{27}$ consists of horses (kuda), buffaloes (karau), goats (bibi), chickens (manu), golden pectoral plates (belak) worn by men, war swords (surik), money (osan), and gold (osan mea). In addition to the pre-eminent gift of the person of the bride herself, the counter-prestations (kesakai) consist of cloth (tais), pigs (fahi), rice (fos), and coral necklaces (barae) worn by women. The components of both sets of prestations are unequal in prestige. In the otaweli the prime gifts are the horse and buffalo, with the belak and surik ranking below them, and the goats and chickens still further below. In the kesakai the barae rank at the bottom of the prestige chain. With its ever-increasing acceptance in Naueti society today, money can substitute for the animals and the barae.

\section{Conclusions}

The above analysis has established that the Naueti practise asymmetric alliance as an institution and classify kin and affines according to a relationship terminology of asymmetric prescriptive alliance. This finding leads to certain conclusions that have relevance for the comparative study of relationship systems in eastern Indonesia. In the study of Timorese relationship terminologies (Hicks 1990) to which I alluded in my opening remarks, I attempted to demonstrate how certain terminologies in the region of Timor might have evolved, specifically arguing that on the basis of the data available at that time one feasible evolutionary progression might be construed to be as follows:

Symmetric prescriptive terminology with exogamous moieties (no instance in Indonesia) $\rightarrow$ symmetric prescriptive terminology with no moieties (Atoni (patrilineal), Northern Tetum (matrilineal)) $\rightarrow$ transitional terminology (Mbae of western Flores (predominately symmetric), Kairui (predominately symmetric), Makassai (predominately asymmetric)) $\rightarrow$ asymmetric prescriptive terminology (Ema, Kédang (no asymmetric alliances), ${ }^{28}$ Mambai, Lamaholot, Western Manggarai) $\rightarrow$ non-prescriptive, but lineal (ViquequeTetum) $\rightarrow$ non-lineal (Bunak). ${ }^{29}$

27 The term most generally used throughout East Timor is folin, a word borrowed from the Tetum language.

28 A population located on the island of Lomblen, eastern Indonesia (Barnes 1974).

29 The Lamaholot-speaking people are found in eastern Flores and on adjacent islands in the archipelago, including Solor. 
It will be recalled that Hull has suggested that the Kairui, Waimaha, Midiki, and Naueti languages are so closely related as to merit being classed as dialects of the hypothetical mother-language 'Kawamina'. Until my recent research in East Timor only the relationship terminology of the Kairui was known in any detail, although I had previously recorded some seven (Hicks 1973:480) terms used by the Waimaha. For what they are worth, the Waimaha terms closely resemble those of the Kairui, though of course they are far too exiguous to make it possible to discern the structure of the Waimaha terminology. Although our knowledge of the Midiki relationship terms is even more tenuous, the Kairui terminology, as already noted, is sufficiently well described to be seen as occupying a transitional stage between the stages of symmetry and asymmetry, with rather more of an inclination towards symmetry. However, now that we have the complete set of terms from the fourth Kawamina dialect at hand, we can see that the Naueti relationship terminology is itself transitional between that of the Kairui and Makassai, on the one hand, and the non-prescriptive terminology of the Viqueque Tetum (Hicks 1978b), on the other. In respect of the above schema remarked above, that is, from asymmetric prescription to non-linearity (cognation), the contemporary Naueti terminology might be understood as having evolved from the stage of symmetry/asymmetry exemplified by their linguistic congeners, the Kairui, into one of fully-fledged asymmetry displayed by the Ema of central East Timor, Kédang of Lomblen (Barnes 1974), Mambai of central East Timor, Lamaholot of eastern Flores (Barnes 1977), and Western Manggarai of western Flores (Hicks 1984).

Alternatively, in the sequence model proposed by Guermonprez, in which directionality flows in the opposite direction, the Bunak would represent the prototypical stage and symmetric prescription would represent its culmination. In his schema the Naueti asymmetric terminology would now be interpreted as having evolved from a terminology of lineal non-prescription (Viqueque Tetum) and incrementally subject to movement towards nonlinearity (Bunak). Thereafter its evolution would direct itself towards the 'transitional' systems of the Makassai and Kairui and thence the symmetric terminologies exemplified by the Northern Tetum, and Atoni. Thus:

Non-lineal (Bunak) $\rightarrow$ non-prescriptive, but lineal (ViquequeTetum) $\rightarrow$ asymmetric prescriptive terminology (Ema, Kédang (no asymmetric alliances), Mambai, Lamaholot, Western Manggarai, Naueti) $\rightarrow$ transitional terminology (Mbae of western Flores (predominately symmetric), Kairui (predominately symmetric), Makassai (predominately asymmetric) $\rightarrow$ symmetric prescriptive terminology with no moieties (Atoni (patrilineal), Northern Tetum (matrilineal)) $\rightarrow$ symmetric prescriptive terminology with exogamous moieties (no instance in Indonesia). ${ }^{30}$

30 In light of the fact that the Mambai appear in the above schemata, Guermonprez's comment (1998:291, note), that their terminology has not been published needs correcting, since an analysis of Mambai relationship categories had, in fact, appeared twenty years earlier (Hicks 1978a:103-11). Again, in discussing verbal expressions used in eastern Indonesia for 'wife-takers' 
The wider conclusion emerging from this investigation, however, involves geographical amplitude. Figure 2 shows the respective locations of the Mambai and Naueti, populations separated by a distance of about fifty kilometres of rugged country occupied by up to half a dozen other ethnolinguistic groups. Bearing in mind the current status of the Mambai terminology as marking the eastern limits of such systems of nomenclature, it is evident that these limits must now be adjusted to accommodate the findings of the present analysis. The Naueti relationship terminology may now be regarded as the most easterly instance yet discovered of asymmetric prescriptive alliance in Southeast Asia.

\section{Acknowledgements}

My first period of research on Naueti culture commenced in 1966 in the Viqueque subdistricts of Uato Carabau and Uato Lari, and in Viqueque subdistrict itself, with funding provided by the London Committee of the LondonCornell Project for East and South East Asian Studies, which was supported jointly by the Carnegie Corporation of New York and the Nuffield Foundation. Research was renewed in Viqueque in 1999 with a grant from the American Philosophical Society and continued intermittently and as part of other projects for almost eight months in 2005 with funding from the J. William Fulbright Foreign Scholarship Board. I would like to single out for special thanks the following individuals who were particularly helpful in aiding me prepare this paper: Mr. José Caetano Guterres, Mr. Jaquita da Costa Guterres, and Mr. Max Stahl. Further thanks are extended to the anonymous reviewers who made suggestions for improving it.

and 'wife-givers', Guermonprez (1998:286) states that 'these expressions are used when necessary to distinguish the two kinds of affines merged by the kinship vocabulary'. This is indeed correct. However, in going on to add 'To my knowledge, the published ethnography on Eastern Indonesia contains no explicit information on this subject' (Guermonprez 1998:292, note) he invites reference to two such populations who do, as a matter of fact, employ this very device. For the Kairui it has been noted that 'This diagnosis confers upon the Kairui terminology a distinctive interest, for the term for the bilateral female cross-cousin (sai) is modified by the terms appropriate to wife-giver (umane) and wife-taker (uasa) to distinguish between the two lines, a device suggesting in the developmental sequence that this terminology falls between the symmetry of the Northern Tetum and Mbae, and the asymmetry of the western Manggarai' (Hicks 1990:67). The same verbal resource appears in the relationship terminology of the aforementioned Makassai, where the bilateral category sai (minimal specifications: MBC, FZC) may be qualified when situationally required by the terms for 'wife-giver' (umaraha) or 'wife-taker' (tupumata) respectively (Hicks 1990:73-4). 


\section{References}

Almeida, António de

1994 'Da origem lendária e mitólogica dos povos do Timor português', in: $O$ oriente de expressão portuguesa, pp. 577-607. Lisboa: Fundação Oriente, Centro de Estudos Orientais.

Barnes, R.H.

1974

Kédang; A study of the collective thought of an eastern Indonesian people. With a forword by Rodney Needham. Oxford: Clarendon Press. [Oxford Monographs on Social Anthropology.]

1977 'Alliance and categories in Wailolong, East Flores', Sociologus 27:133-75.

Capell, A.

1943/1944 'Peoples and languages of Timor', Oceania 14:191-219, 311-37; 15:19-48.

Cunningham, Clark E.

1967 'Atoni kin categories and conventional behavior', Bijdragen tot de Taal-, Land-en Volkenkunde 123:53-70.

Evans-Pritchard, E.E.

1951 Social anthropology. London: Cohen and West.

Forth, Gregory L.

1981 Rindi; An ethnographic study of a traditional domain in eastern Sumba. The Hague: Nijhoff. [KITLV, Verhandelingen 93.]

Guermonprez, Jean-François

1998 'Transformations of kinship systems in eastern Indonesia', in: Maurice Godelier, Thomas R. Trautman and Franklin E. Tjon Sie Fat (eds), Transformations of kinship, pp. 271-93. Washington, DC/London: Smithsonian Hicks, David Institution Press. [Smithsonian Series in Ethnographic Inquiry.]

1978a 'The Mambai; Asymmetric prescriptive alliance in Timor', in: David Hicks, Structural analysis in anthropology; Case studies from Indonesia and Brazil, pp. 103-11. St. Augustin bei Bonn: Verlag des Anthropos-Instituts. [Studia Instituti Anthropos 30.]

1978b 'Structure and change; A relationship terminology in transition', in: David Hicks, Structural analysis in anthropology; Case studies from Indonesia and Brazil, pp. 113-25. St. Augustin bei Bonn: Verlag des Anthropos-Instituts. [Studia Instituti Anthropos 30.]

1981 'A two section system with matrilineal descent among the Tetum of eastern Indonesia', Sociologus 31-2:181-4.

1983 'A transitional relationship terminology of asymmetric prescriptive alliance among the Makassai of eastern Indonesia', Sociologus 33-1:73-85.

1984 'A relationship terminology of asymmetric prescriptive alliance among the Manggarai of eastern Indonesia', Anthropos 79:517-21.

1985 'A transitional two-section system among the Mbae-speakers of Manggarai, eastern Indonesia', Sociologus 35-1:74-83.

1986 'The relationship terminology of the Ema', Sociologus 36-2:162-71.

1987 'Cognation and generalized exchange', Sociologus 37-2:177-80. 
1989 'Confirmations and corrections; Tetum terms of relationship from Central Timor', Sociologus 39-2: 153-60.

$1990 \quad$ Kinship and religion in eastern Indonesia. Götenborg: Acta Universitatis Gothoburgensis. [Gothenburg Studies in Social Anthropology 12.]

2004 Tetum ghosts and kin; Fertility and gender in East Timor. Second edition. Long Grove, Illinois: Waveland. [First edition 1976.]

Leach, E.R.

1961 Rethinking anthropology. London: Athlone. [London School of EconoLévi-Strauss, Claude mics, Monographs on Social Anthropology 23.]

1949 Les structures élémentaires de la parenté. Paris: Presses Universitaires de France. [Bibliothèque de Philosophie Contemporaine, Psychologie et Sociologie.]

Molnar, Andrea Katalin

2000 Grandchildren of the Ga'é ancestors; Social oganization and cosmology among

Needham, Rodney the Hoga Sara of Flores. Leiden: KITLV Press. [Verhandelingen 185.]

1960 'Alliance and classification among the Lamet', Sociologus 10-2:97-119.

1967 'Terminology and alliance II. Mapuche; Conclusions'. Sociologus 17:3954.

Renard-Clamagirand, Brigitte

1987 Marobo; Une société Ema de Timor. Préface de Georges Condominas. Paris: Société d'Études Linguistiques et Anthropologiques de France. [Langues et Civilisations de l'Asie du Sud-Est, de l'Océan indien et de la Réunion 12.]

Rodgers, Susan

1984 'Orality, literacy, and Batak concepts of marriage alliance', Journal of Anthropological Research 40-3:433-50.

Saunders, George

2002-03 'Comparative vocabulary of the Naueti dialect', Estudos de Linguas e Culturas de Timor Leste/Studies in Languages and Cultures of East Timor 5:79-106.

Smedal, Olaf H.

2002 'Ngadha relationship terms in context; Description, analysis, and implications', Asian Journal of Social Science 30-3:493-524.

Wouden, Franciscus Antonius Evert van

[1935] Sociale structuurtypen in de Groote Oost. Leiden: Ginsberg. [PhD thesis, Leiden University.] 